\title{
PENGARUH MODEL PEMBELAJARAN DAN MINAT BELAJAR TERHADAP HASIL BELAJAR PKn
}

\author{
T. Herlina ${ }^{1}$, Harun Sitompul ${ }^{2}$, R. Mursid ${ }^{3}$ \\ ${ }^{1}$ Sekolah Dasar Swasta Kecamatan Medan Tembung, Sumatera Utara \\ ${ }^{2,3}$ Program Pascasarjana, Universitas Negeri Medan, Medan \\ Itherlina42@yahoo.com; ${ }^{2}$ prof_runsit@yahoo.co.id; mursid.tp@gmail.com
}

\begin{abstract}
Abstrak: Penelitian ini bertujuan untuk mengetahui : (1) Perbedaan hasil belajar PKn antara siswa yang diajar dengan model pembelajaran kooperatif tipe STAD dan siswa yang diajar dengan model pembelajaran ekspositori; (2) Perbedaan hasil belajar PKn antara siswa yang memiliki minat belajar tinggi dan siswa yang memiliki minat belajar rendah; (3) Interaksi antara model pembelajaran dan minat belajar terhadap hasil belajar PKn. Hasil penelitian ini menunjukkan bahwa: (1) rata-rata hasil belajar PKn siswa yang diajar dengan model pembelajaran kooperatif tipe STAD lebih tinggi daripada model pembelajaran ekspositori; (2) rata-rata hasil belajar PKn siswa yang memiliki minat belajar tinggi lebih tinggi daripada minat belajar rendah; (3) terdapat interaksi antara model pembelajaran dan minat belajar siswa dalam mempengaruhi hasil belajar PKn.
\end{abstract}

Kata Kunci: Model Pembelajaran, Minat Belajar, Hasil Belajar PKn

Abstract: This study aims to determine: (1) Differences in learning outcomes of Civics between students taught by STAD type cooperative learning model and students are taught by expository learning model; (2) differences in learning outcomes between students who have high learning interest and students who have low learning interest; (3) The interaction between the learning model and the interest of learning on the learning outcomes of Civics. The results of this study indicate that: (1) the average of students' learning outcomes taught by STAD type cooperative learning model is higher than the expository learning model; (2) average learning outcomes of Civics students who have high learning interest higher than low learning interest; (3) there is an interaction between the learning model and the students' learning interest in influencing the learning outcomes of Civics.

Keyword: Learning Models, Interest to Learn, Learning outcomes Civics

\section{PENDAHULUAN}

Guru sebagai pendidik dituntut semakin berperan dalam mempersiapkan dan membenahi diri untuk menjadi guru yang berkualitas, memiliki kompetensi inovatif dan antisipasi terhadap perkembangan ilmu pengetahuan dan teknologi dalam era industrialisasi sekarang ini. Guru dapat menciptakan kondisi belajar sedemikian rupa dengan menggunakan strategistrategi pembelajaran yang inovatif dan menarik, sehingga setiap anak didik merasa tertarik untuk belajar Pendidikan Kewarganegaraan (PKn) yang pada akhirnya dapat meningkatkan hasil belajar siswa.

Trianto (2010) menjelaskan bahwa suatu pembelajaran dikatakan efektif apabila memenuhi persyaratan utama keefektifan pengajaran yaitu sebagai berikut: (1) Presentasi waktu belajar siswa yang tinggi dicurahkan terhadap KBM; (2) Rata-rata perilaku melaksanakan tugas yang tinggi di antara siswa; (3) Ketetapan antara kandungan materi pembelajaran dengan kemampuan siswa (orientasi keberhasilan belajar); (4) Mengembangkan suasana belajar yang akrab dan positif, serta mengembangkan struktur kelas yang lebih inovatif.

Namun pada kenyataannya, hasil belajar PKn masih cenderung kurang memuaskan. Rendahnya hasil belajar para siswa dikarenakan pemilihan model pembelajaran yang kurang tepat, jadi siswa cenderung merasa bosan pada saat guru menjelaskan pelajaran dan siswa cenderung menjadi pasif atau dengan kata lain, kegiatan pembelajaran di kelas berpusat pada guru atau teacher center.

Akibatnya pengetahuan siswa terbatas hanya pada apa yang dijelaskan oleh guru di 
kelas sehingga kurang memacu pada pola berpikir, kreativitas atau potensi siswa kurang mengakses memori jangka panjang siswa terhadap materi pelajaran yang disampaikan oleh guru. Model pembelajaran konvensional atau ceramah mendominasi dalam proses belajar mengajar bidang studi PKn di SD Swasta Kecamatan Medan Tembung. Hal ini yang menyebabkan siswa menjadi jenuh, bosan dan pasif, karena kurangnya pemahaman siswa terhadap konsep pembelajaran PKn.

Peserta didik belum dapat menyerap hal yang bersifat abstrak, bahwa tingkat pemahaman tiap-tiap siswa tidak sama sehingga kecepatan siswa dalam mencerna bahan pengajaran berbeda. Maka tugas seorang guru di kelas tidak hanya membantu siswa memahami konsep yang diberikan dan membantu para siswa mengaplikasikan konsep tersebut. Seorang guru bukan hanya sekedar menyampaikan materi yang baik dan benar tetapi harus dapat menciptakan suasana belajar yang menyenangkan yang dapat memotivasi potensi otak siswa dan dapat mengakomodasi gaya belajar siswa, oleh karena itu diperlukan adanya perbaikan dalam proses belajar mengajar.

Menurut Pidarta (2009) belajar adalah perubahan perilaku yang relatif permanen sebagai hasil pengalaman (bukan hasil perkembangan, pengaruh obat, atau kecelakaan) dan bisa melaksanakannya pada pengetahuan lain serta mampu mengkomunikasikannya kepada orang lain. Seseorang dianggap telah belajar sesuatu jika dia dapat menunjukkan perubahan perilakunya. Menurut teori ini dalam belajar yang penting adalah input yang berupa stimulus dan output yang berupa respon. Stimulus adalah apa saja yang diberikan guru kepada pebelajar, sedangkan respon berupa reaksi atau tanggapan pebelajar terhadap stimulus yang diberikan oleh guru tersebut. Proses yang terjadi antara stimulus dan respon tidak penting untuk diperhatikan karena tidak dapat diamati dan tidak dapat diukur. Yang dapat diamati adalah stimulus dan respon, oleh karena itu apa yang diberikan oleh guru (stimulus) dan apa yang diterima oleh pebelajar (respon) harus dapat diamati dan diukur. Teori ini mengutamakan pengukuran, sebab pengukuran merupakan suatu hal penting untuk melihat terjadi atau tidaknya perubahan tingkah laku tersebut.

Selain itu, Slameto (2010) menjelaskan bahwa belajar adalah suatu proses usaha yang dilakukan sesorang untuk memperoleh suatu perubahan tingkah laku yang baru secara 222 keseluruhan, sebagai hasil pengalamannya sendiri dalam interaksi dengan lingkungannya. Belajar yang efektif dan efesien dapat tercapai apabila dapat menggunakan model belajar yang tepat. Model belajar diperlukan untuk dapat mencapai hasil yang semaksimal mungkin. Banyak model pembelajaran yang dapat digunakan untuk menentukan keberhasilan suatu proses pembelajaran di kelas, salah satu model pembelajaran yang dapat digunakan pembelajaran yang dapat digunakan adalah model pembelajaran aktif. Pembelajaran aktif merupakan pendekatan pembelajaran yang mengajak siswa untuk belajar aktif.

Syah (2010) mengemukakan belajar adalah kegiatan yang berproses dan merupakan unsur yang sangat fundamental dalam penyelenggaraan setiap jenis dan jenjang pendidikan. Ini berarti bahwa berhasil atau gagalnya pencapaian tujuan pendidikan itu amat bergantung pada proses belajar yang dialami siswa, baik ketika ia berada di sekolah maupun di lingkungan rumah atau keluarganya sendiri.

Kemudian Suryabrata (2008) menjelaskan bahwa di dalam belajar terdapat beberapa hal yang pokok untuk dipahami yaitu: (1) belajar membawa perubahan dalam arti behavioural change (perubahan tingkah laku), aktual maupun potensial, (2) perubahan tersebut pada pokoknya adalah didapatkannya kecakapan baru, (3) perubahan itu terjadi karena usaha-usaha atau dengan sengaja. Perubahan yang terjadi dalam diri seseorang banyak sekali baik sifat maupun jenisnya karena itu sudah tentu tidak setiap perubahan dalam diri sesorang merupakan perubahan dalam arti belajar.

Pembelajaran mencapai puncaknya pada hasil belajar atau unjuk kerja siswa, hasil belajar merupakan hasil proses belajar. Dalam hal ini Slameto (2010) mendefinisikan hasil belajar siswa pada hakikatnya adalah perubahan tingkah laku sebagai hasil belajar dalam pengertian yang lebih luas mencakup bidang kognitif, afektif, dan psikomotorik. Sardiman (2009) juga menyebutkan hasil belajar merupakan hasil dari suatu interaksi tindak belajar dan tindak mengajar. Dari sisi guru, tindak mengajar diakhiri dengan proses evaluasi hasil belajar. Dari sisi siswa, hasil belajar merupakan berakhirnya pengajaran dari puncak proses belajar.

Lebih lanjut Sadirman (2009) menyatakan ada tiga kemampuan yang diharapkan siswa sebagai hasil belajar yaitu (1) ranah kognitif (2) ranah afektif (3) ranah Psikomotor. Kognitif Domain yaitu perilaku yang berhubungan dengan 
pengetahuaan ingatan, pemahaman, menjelaskan, menguraikan, merencanakan, menilai dan menerapkan. Affective Domain yaitu perilaku yang berhubungan dengan sikap menerima, memberikan respons, menilai, organisasi, dan karekteristik. Psychomotor Domain yaitu perilaku yang berhubungan dengan ketrampilan atau skills yang berkaitan dengan fisik.

Menurut Bloom seperti dikutip oleh Sudjana (2009) ranah kognitif berkenaan dengan hasil belajar intelektual yang terdiri dari enam aspek, yakni (a) Pengetahuan, (b) Pemahaman, (c) Aplikasi, (d) Analisis, (e) Sintesis, (f) Evaluasi.

Selanjutnya berkaitan dengan faktor yang mempengaruhi hasil belajar dijelaskan oleh Sardiman (2009) menyebutkan faktor-faktor yang mempengaruhi hasil belajar sebagai berikut: (1) Faktor internal meliputi: faktor fisiologis dan faktor psikologis. (2) Faktor eksternal meliputi: Faktor lingkungan alam, faktor instrumental, dan faktor sosial.

Hal senada diungkapkan oleh Slameto (2010) bahwa faktor-faktor yang mempengaruhi hasil belajar adalah: (1) Faktor internal dan (2) Faktor eksternal. Faktor internal terdiri dari 3 faktor antara lain sebagai berikut: jasmaniah (kesehatan, cacat tubuh), faktor psikologis (intelegensi, perhatian, minat, bakat, motif, kematangan, kesiapan), dan faktor kelelahan. Sedangkan faktor eksternal adalah faktor yang ada di luar diri siswa atau individu terdiri dari atas tiga faktor yaitu: (1) Faktor keluarga: (cara orang tua mendidik, relasi antar anggota keluarga, suasana rumah, keadaan ekonomi keluarga, pengertian orang tua, latar belakang kebudayaan); (2) Faktor sekolah: (metode mengajar, kurikulum, relasi guru dengan siswa, disiplin sekolah, alat pelajaran, waktu sekolah, standar pelajaran di atas ukuran, keadaan gedung, metode belajar, tugas rumah), dan; (3) Faktor masyarakat (kegiatan siswa dalam masyarakat, mass media, teman bergaul, bentuk kehidupan masyarakat).

Berkaitan dengan bidang studi PKn, pembelajaran $\mathrm{PKn}$ merupakan salah satu pelajaran pokok di sekolah yang bertujuan untuk mengembangkan kecerdasan warga negara dalam dimensi spritual, rasional, emosional dan sosial, mengembangkan tangung jawab sebagai warga negara, serta mengembangkan anak didik berpartisipasi sebagai warga negara yang baik . Selain itu, tujuan PKn dapat dilihat dalam UUD Republik Indonesia Nomor 20 tahun 2003 tentang sistem Pendidikan Nasional pada bagian penjelasan pasal 37 ayat (1) bahwa "Pendidikan kewarganegaraan dimaksudkan untuk membentuk peserta didik menjadi manusia yang memiliki rasa kebangsaan dan cinta tanah air". Oleh karena itu, PKn diharapkan dapat mempersiapkan peserta didik menjadi warga negara yang memiliki komitmen yang kuat dan konsisten untuk mempertahankan Negara Kesatuan.

Salah satu model pembelajaran inovatif yang bisa dikembangkan dan diterapkan oleh guru PKn kelas V SD yaitu model pembelajaran kooperatif tipe STAD.

Joyce dan Weil (dalam Rusman, 2011) berpendapat bahwa model pembelajaran adalah suatu rencana atau pola yang dapat digunakan untuk membentuk kurikulum (rencana pembelajaran jangka panjang), merancang bahanbahan pembelajaran, dan membimbing pembelajaran di kelas atau yang lain. Model pembelajaran dapat dijadikan pola pilihan, artinya para guru boleh memilih model pembelajaran yang sesuai dan efisien untuk mencapai tujuan pendidikannya. Menurut Suprijono (2010), model pembelajaran ialah pola yang digunakan sebagai pedoman dalam merencanakan pembelajaran di kelas maupun tutorial.

Berkenaan dengan model pembelajaran, Bruce Joyce dan Marsha Weil (dalam Suprijono, 2010) mengetengahkan 4 kelompok model pembelajaran, yaitu: (1) model interaksi sosial, (2) model pengolahan informasi, (3) model personal- humanistik, dan (4) model modifikasi tingkah laku. Kendati demikian, sering kali penggunaan istilah model pembelajaran tersebut diidentikkan dengan strategi pembelajaran. Model pembelajaran berfungsi pula sebagai pedoman bagi para perancang pembelajaran dan para guru dalam merencanakan aktivitas belajar mengajar.

Suprijono (2010) mengemukakan bahwa model pembelajaran memiliki ciri-ciri yakni: (1) Berdasarkan teori pendidikan dan teori belajar dari para ahli tertentu. Model ini dirancang untuk melatih partisipasi dalam kelompok secara demokratis. (2) Mempunyai misi atau tujuan pendidikan tertentu, misalnya model berpikir induktif dirancang untuk mengembangkan proses berpikir induktif. (3) Dapat dijadikan pedoman untuk perbaikan kegiatan belajar mengajar di kelas, misalnya model synectic dirancang untuk memperbaiki kreativitas dalam pelajaran mengarang. (4) Memiliki bagian-bagian model yang dinamakan: (a) urutan langkah-langkah 
pembelajaran, (b) adanya prinsip-prinsip reaksi, (c) sistem sosial, dan (d) sistem pendukung. Keempat bagian tersebut merupakan pedoman praktis bila guru akan melaksanakan suatu model pembelajaran. (5) Memiliki dampak sebagai akibat penerapan model pembelajaran. Dampak tersebut meliputi: (a) dampak pembelajaran, yaitu hasil belajar yang dapat diukur, (b) dampak pengiring, yaitu hasil belajar jangka panjang. (6) Membuat persiapan mengajar (desain intruksional) dengan pedoman model pembelajaran yang dipilihnya.

Lie (2007) menyebutkan cooperative learning dengan istilah pembelajaran gotong royong, yaitu sistem pembelajaran yang memberi kesempatan kepada siswa lain dalam tugas-tugas terstruktur. Menurut Sanjaya (2011) model pembelajaran kelompok adalah rangkaian kegiatan belajar yang dilakukan oleh siswa dalam kelompok-kelompok tertentu untuk mencapai tujuan pembelajaran yang telah dirumuskan. Kemudian menurut Isjoni (2011) model pembelajaran kooperatif adalah suatu strategi pembelajaran dimana sistem belajar dan bekerja dalam kelompok-kelompok kecil yang berjumlah 4-6 orang secara kolaboratif sehingga dapat merangsang siswa lebih bergairah dalam belajar.

Sanjaya (2011) menjelaskan terdapat empat prinsip dasar pembelajaran kooperatif yakni: (1) prinsip ketergantungan positif, (2) tanggungjawab perseorangan, (3) interaksi tatap muka, dan (4) partisipasi dan komunikasi. Dari prinsip-prinsip di atas, berarti pembelajaran kooperatif lebih menekankan pada pembelajaran siswa untuk lebih aktif dalam pembelajaran. Pembelajaran yang dilakukan dengan berkelompok itu pun harus ada kerja sama untuk menemukan dan membangun pengetahuan sehingga anak dapat termotivasi belajar. Motivasi belajar dengan didukung pembelajaran yang menyenangkan agar anak bosan mengikuti pembelajaran.

Lebih lanjut Sanjaya (2011) berpendapat bahwa terdapat empat unsur penting dalam pembelajaran kooperatif yang harus diterapkan yakni: (1) adanya peserta dalam kelompok (2) adanya aturan kelompok (3) adanya upaya belajar setiap kelompok anggota (4) adanya tujuan yang harus dicapai .Guru perlu menyusun jadwal untuk mengevaluasi proses kerja kelompok dan hasil kerjasama mereka, agar kerjasama berikutnya bisa lebih efektif. Waktu evaluasi tidak perlu diadakan setiap kerja kelompok, tapi bisa diadakan selang beberapa kali dilaksanakan pembelajaran kooperatif.
Isjoni (2011) mengemukakan bahwa model pembelajaran kooperatif tipe STAD dikembangkan oleh Slavin dan merupakan salah satu tipe kooperatif yang menekankan pada adanya aktivitas dan interaksi antar anggota kelompok belajar yang terdiri dari 4-6 siswa dengan tingkat kemampuan dan jenis kelamin yang berbeda untuk saling memotivasi dan membantu dalam menguasai materi pelajaran guna mencapai prestasi yang maksimal.

Model pembelajaran kooperatif tipe STAD menekankan bagaimana dalam proses pembelajaran, siswa dibagi menjadi beberapa kelompok secara heterogen, terjadi saling kerjasama antara yang satu dengan lain, bisa saling bertukar pikiran, berbagi tangungjawab, bisa saling memahami antara yang satu dengan yang lain, sehingga bisa dilihat ketrampilan sosial yang dimilikinya. Pembelajaran kooperatif tipe STAD, dengan ciri utama berupa penilaian dalam bentuk kuis yang berefek pada penghargaan terhadap individu dan kelompok.

Penerapan model pembelajaran kooperatif tipe STAD juga sangat bermanfaat bagi siswa yaitu sebagai berikut: (1) membantu siswa mempelajari isi materi pelajaran yang sedang dibahas; (2) adanya anggota kelompok lain yang menghindari kemungkinan siswa mendapat nilai rendah, karena dalam tes lisan siswa dibantu oleh anggota kelompoknya; (3) pembelajaran kooperatif menjadikan siswa mampu belajar berdebat, belajar mendengarkan pendapat orang lain, dan mencatat hal-hal yang bermanfaat untuk kepentingan bersama-sama; (4) pembelajaran kooperatif menghasilkan pencapaian belajar siswa yang tinggi menambah harga diri siswa dan memperbaiki hubungan dengan teman sebaya; (5) hadiah atau penghargaan yang diberikan akan memberikan dorongan bagi siswa untuk mencapai hasil yang lebih tinggi; (6) siswa yang lambat berpikir dapat dibantu untuk menambah ilmu pengetahuan; (7) pembentukan kelompokkelompok kecil memudahkan guru untuk memonitor siswa dalam belajar bekerja sama.

Menurut Ibrahim, dkk (2010) langkahlangkah model pembelajaran kooperatif tipe STAD adalah sebagai berikut: (1) menyampaikan tujuan dan memotivasi siswa; (2) menyajikan atau menyampaikan informasi; (3) mengorganisasikan siswa dalam kelompok belajar; (4) membimbing siswa bekerja dan belajar; (5) melakukan evaluasi; (6) memberikan penghargaan.

$\begin{array}{cccc}\text { Menurut } & \begin{array}{c}\text { Sanjaya } \\ \text { pembelajaran }\end{array} & \begin{array}{c}(2011), \\ \text { ekspositori }\end{array} & \text { model } \\ \text { adalah } & \text { model }\end{array}$


pembelajaran yang menekankan kepada proses penyampaian materi secara verbal dari seorang guru kepada sekelompok siswa yang bertujuan untuk meningkatkan kreasi belajar siswa. Hakikatnya, guru memandang bahwa mengajar itu adalah penyajian ilmu pengetahuan kepada siswa, dan siswa dipandang sebagai penerima apa yang disampaikan guru. Kondisi yang berlangsung adalah proses komunikasi satu arah, sehingga mengakibatkan partisipasi kelompok belajar siswa terbatas pada mendengarkan dan mencatat apa yang disampaikan oleh guru. Dengan demikian dapat dipahami bahwa dalam pembelajaran ekspositori guru bertindak sebagai narasumber tunggal dan siswa belajar dari guru tersebut.

Dimyati dan Mudjiono (2009) menjelaskan bahwa model pembelajaran ekspositori adalah model pembelajaran yang terpusat pada guru dimana guru aktif memberikan penjelesan atau informasi tentang bahan ajar. Siswa diasumsikan sebagai seorang individu yang belum dewasa dan belum memiliki pengetahuan dari ketrampilan, jadi dalam proses interaksi guru dan siswa, siswa merupakan objek sedangkan guru merupakan sumber ilmu dan ketrampilan, kehadiran guru di depan kelas merupakan suatu kondisi mutlak yang harus agar proses pembelajaran berlangsung. Pembelajaran ekspositori lebih menekankan pada proses pembelajaran oleh pengajar (teacher teaching), guru melaksanakan tugas dan strategi pembelajaran yang digunakan hampir sama untuk setiap materi pelajaran.

Penerapan strategi pembelajaran ekspositori berdasarkan asumsi sebagaimana dijelaskan Lie (2007) yaitu: (1) proses pembelajaran merupakan usaha memindahkah pengetahuan guru kesiswa (tugas seorang guru adalah menerima, guru, memberikan informasi dan mengharapkan siswa untuk menghafal dan mengingatnya), (2) siswa dianggap botol kosong yang siap diisi dengan pengetahuan (siswa adalah penerima pengetahuan pasif, guru memiliki pengetahuan pasif, guru memiliki pengetahuan yang nantinya dihafal oleh siswa), (3) menkotakkotakkan siswa (guru mengelompokkan siswa berdasarkan nilai dan masukan siswa dalam kategori, pengelompokkan yang homogen, siapa yang layak mengikuti unggulan dan siapa yang tidak layak), (4) memacu siswa dalam kompetisi (siswa bekerja keras untuk mengalahkan teman sekelasnya, siapa yang kuat, dia yang menang, orang tua pun saling bersaing menyombongkan anaknya masing-masing dan menonjolkan prestasi anaknya bagaikan memamerkan ayam aduan).

Sanjaya (2011) menambahkan model pembelajaran ekspositori akan berlangsung secara efektif apabila: (a) guru akan menyapaikan bahan-bahan pelajaran baru serta kaitanya dengan yang akan dan harus dipelajari oleh siswa. Biasanya bahan atau materi baru itu diperlukan untuk kegiatan-kegiatan khusus seperti kegiatan pemecahan masalah atau materi-materi dasar, seperti konsep-konsep tertentu, prosedur atau rangkaian aktivitas, dan lain sebagainya, (b) apabila guru menginginkan agar siswa mempunyai gaya model intelektual tertentu, misalnya agar siswa mengingat bahan pelajaran sehingga siswa dapat mengungkapkannya kembali, (c) jika bahan pelajaran yang akan diajarkan cocok untuk dipresentasikan, artinya dipandang dari sifat dan jenis materi pelajaran, memang materi pelajaran itu mungkin hanya dapat dipahami oleh siswa apabila disampaikan oleh guru misalnya, materi pelajaran hasil penelitian berupa data-data khusus, (d) jika ingin membangkitkan keingintahuan siswa tentang topik-topik tertentu. Misalnya, materi pelajaran yang bersifat pancingan untuk meningkatkan motivasi belajar siswa, (e) guru menginginkan mendemonstrasikan suatu teknik atau langkah baku atau langkah yang standar yang harus diamati, maka dapat menimbulkan pengaruh atau resiko tertentu, (f) apabila seluruh siswa memiliki tingkat kesulitan yang sama, sehingga guru perlu akan menjelaskan untuk seluruh siswa, dan (g) apabila guru mengajarkan sekelompok siswa yang rata-rata memiliki kemampuan yang rendah.

Di samping pembelajaran yang tepat yang dilaksanakan guru dalam kelas, hal lain yang dianggap tidak kalah pentingnya adalah sikap positif siswa terhadap pembelajaran PKn yang dapat mengakibatkan minat belajar siswa juga akan meningkat. Guru perlu menumbuhkan minat belajar siswa tumbuh dan berkembang terutama kepada penekanan pada minat belajar siswa yang tumbuh dari dalam diri siswa. Minat belajar siswa akan meningkat apabila kesadaran siswa akan pentingnya materi pelajaran yang disampaikan guru. Di samping kesadaran yang dapat memupuk minat belajar siswa meningkatkan, juga tujuan yang jelas dari materi yang disampaikan guru membuat siswa paham ke arah mana ia inginkan dan minat belajar siswa akan meningkat.

Syah (2010) mengemukakan minat adalah kecenderungan dan kegairahan yang tinggi atau keinginan yang besar terhadap sesuatu. Minat belajar membuat siswa mau belajar tanpa 
terbebani karena dia menyukai pelajaran tersebut. Minat besar pengaruhnya terhadap belajar, karena bila bahan pelajaran yang dipelajari tidak sesuai dengan minat siswa, siswa tidak akan belajar sebaik-baiknya karena tidak ada daya tarik baginya.

Slameto (2010) menjelaskan minat adalah rasa lebih suka dan rasa ketertarikan pada suatu hal atau aktivitas tanpa ada yang menyuruh. Minat pada dasarnya merupakan penerimaan akan suatu hubungan antara diri sendiri dengan sesuatu di luar diri. Semakin kuat dekat suatu hubungan tersebut, maka semakin besar minatnya. Minat belajarlah yang akan mencegah kebosanan ketika belajar. Sehingga siswa dapat terus memperhatikan penjelasan guru bahkan giat belajar di rumah.

Menurut Sanjaya (2011) beberapa cara dapat dilakukan untuk membangkitkan minat belajar siswa di antaranya: (1) Hubungkan bahan pelajaran yang akan diajarkan dengan kebutuhan siswa. Minat siswa akan tumbuh manakala ia dapat menangkap bahwa materi pelajaran itu berguna untuk kehidupannya; (2) Sesuaikan materi pelajaran dengan tingkat pengalaman dan kemampuan siswa. Materi pelajaran yang terlalu sulit untuk dipelajari atau materi pelajaran yang jauh dari pengalaman siswa akan tidak diminati siswa; dan (3) Gunakan pelbagai model dan metode pembelajaran secara bervariasi misalnya diskusi, kerja kelompok, eksperimen, demonstrasi, dan lain sebagainya.

Guru sebagai evaluator berperan untuk meningkatkan minat belajar siswa. Sebagaimana yang diungkapkan oleh Slameto (2010) bahwa minat besar pengaruhnya terhadap belajar karena bila bahan pelajaran yang dipelajari tidak sesuai dengan minat siswa, maka siswa tidak akan belajar sebaik-baiknya karena tidak ada daya tarik baginya.

Masalah penelitian ini dapat dirumuskan yaitu: (1) Apakah terdapat perbedaan hasil belajar PKn antara siswa yang diajar dengan model pembelajaran kooperatif tipe STAD dan siswa yang diajar dengan model pembelajaran ekspositori?; (2) Apakah terdapat perbedaan hasil belajar PKn antara siswa yang memiliki minat belajar tinggi dengan siswa yang memiliki minat belajar rendah? dan; (3) Apakah terdapat interaksi antara model pembelajaran dan minat belajar terhadap hasil belajar PKn?

\section{METODE}

Penelitian ini dilaksanakan di SD Swasta Lentera Harapan dan SD Swasta Al Ulum Medan Kecamatan Medan Tembung. Populasi penelitian adalah seluruh siswa kelas V SD Swasta di Kecamatan Medan Tembung dengan jumlah keseluruhan adalah 415 siswa. Teknik pengambilan sampel dalam penelitian ini adalah teknik sampel acak kelompok (cluster random sampling) yakni dari seluruh kelas dipilih 2 kelas sebagai sampel yang dikenakan perlakuan melalui pemilihan secara acak.

Penelitian ini menggunakan metode eksperimen dengan rancangan quasi eksperimen desain faktorial 2x2. Melalui desain ini dibandingkan pengaruh model pembelajaran kooperatif tipe STAD dan model pembelajaran ekspositori terhadap hasil belajar PKn ditinjau dari minat belajar siswa. Variabel-variabel tersebut selanjutnya dimasukkan dalam desain penelitian sebagaimana terlihat pada Tabel 1 .

Tabel 1. Rancangan Penelitian Desain Faktorial 2x2

\begin{tabular}{ccc}
\hline $\begin{array}{c}\text { Model Pembelajaran } \\
(\mathbf{A})\end{array}$ & $\begin{array}{c}\text { STAD } \\
\left(\mathrm{A}_{\mathbf{1}}\right)\end{array}$ & $\begin{array}{c}\text { Ekspositori } \\
\left(\mathbf{A}_{2}\right)\end{array}$ \\
Minat Belajar $(\mathbf{B})$ & $\mathrm{A}_{1} \mathrm{~B}_{1}$ & $\mathrm{~A}_{2} \mathrm{~B}_{1}$ \\
\hline Tinggi $\left(\mathrm{B}_{1}\right)$ & $\mathrm{A}_{1} \mathrm{~B}_{2}$ & $\mathrm{~A}_{2} \mathrm{~B}_{2}$ \\
\hline Rendah $\left(\mathrm{B}_{2}\right)$ &
\end{tabular}

Keterangan:

A1B1:Hasil belajar PKn kelompok siswa yang diberi perlakuan dengan model pembelajaran kooperatif tipe STAD yang memiliki minat belajar tinggi

A2B1:Hasil belajar PKn kelompok siswa yang diberi perlakuan dengan model pembelajaran ekspositoriyang memiliki minat belajar tinggi

A1B2:Hasil belajar PKn kelompok siswa yang diberi perlakuan dengan model pembelajaran kooperatif tipe STAD yang memiliki minat belajar rendah

A2B2:Hasil belajar PKn kelompok siswa yang diberi perlakuan dengan model pembelajaran ekspositoriyang memiliki 
minat belajar rendah

Teknik analisis data yang digunakan adalah teknik statistik deskriptif dan inferensial. Teknik statistik deskriptif digunakan untuk mendeskripsikan data antara lai: nilai rata-rata, median, modus, varians dan simpangan baku. Teknik inferensial yang akan digunakan adalah teknik analisis data varians (ANAVA) 2 x 2 . Pengujian hipotesis dilakukan pada taraf signifikansi 5\%. Sebelum ANAVA dua jalur dilakukan, terlebih dahulu dilakukan uji persyaratan analisis yakni uji normalitas menggunakan uji Liliefors dan uji homogenitas menggunakan uji Fisher dan uji Bartlett (Sudjana, 2001).

Selanjutnya untuk keperluan pengujian hipotesis, dirumuskan hipotesis statistik sebagai berikut:

Hipotesis pertama:

$$
\begin{aligned}
& \text { Ho : } \mu A_{1} \leq \mu A_{2} \\
& \text { Ha : } \mu A_{1}>\mu A_{2}
\end{aligned}
$$

Hipotesis kedua:

Ho : $\mu B_{1} \leq \mu B_{2}$

$\mathrm{Ha}: \mu B_{1}>\mu B_{2}$

Hipotesis Ketiga:

$$
\begin{aligned}
& \text { Ho: } \mathrm{A} X \mathrm{X}=0 \\
& \text { Ha: } \mathrm{A} \text { X } \mathrm{B} \neq 0
\end{aligned}
$$

\section{HASIL DAN PEMBAHASAN}

\section{Hasil}

Pengujian hipotesis pertama, kedua dan ketiga dilakukan dengaan menggunakan ANAVA dua jalur. Rangkuman hasil perhitungan dapat dilihat pada Tabel 2 berikut ini.

Tabel 2. Rangkuman Hasil Uji ANAVA

\begin{tabular}{lccccc}
\multicolumn{1}{c}{ Sumber Variasi } & $\mathbf{d k}$ & $\mathbf{J K}$ & $\mathbf{R J K}$ & $\mathbf{F}_{\mathbf{h}}$ & $\mathbf{F}_{\mathbf{t}(\mathbf{1 . 5 8})}$ \\
\hline Model Pembelajaran (A) & 1 & 75,80 & 75,80 & 6,66 & 4,01 \\
Minat Belajar (B) & 1 & 250,33 & 250,33 & 22,01 & 4,01 \\
Interaksi (AB) & 1 & 54,24 & 54,24 & 4,77 & 4,01 \\
Galat & 58 & 659,51 & 11,37 & - & - \\
\hline Total & 61 & 1039,87 & - & - & - \\
\hline
\end{tabular}

Bentuk interaksi tersebut dapat dilihat pada Gambar 1 berikut ini:

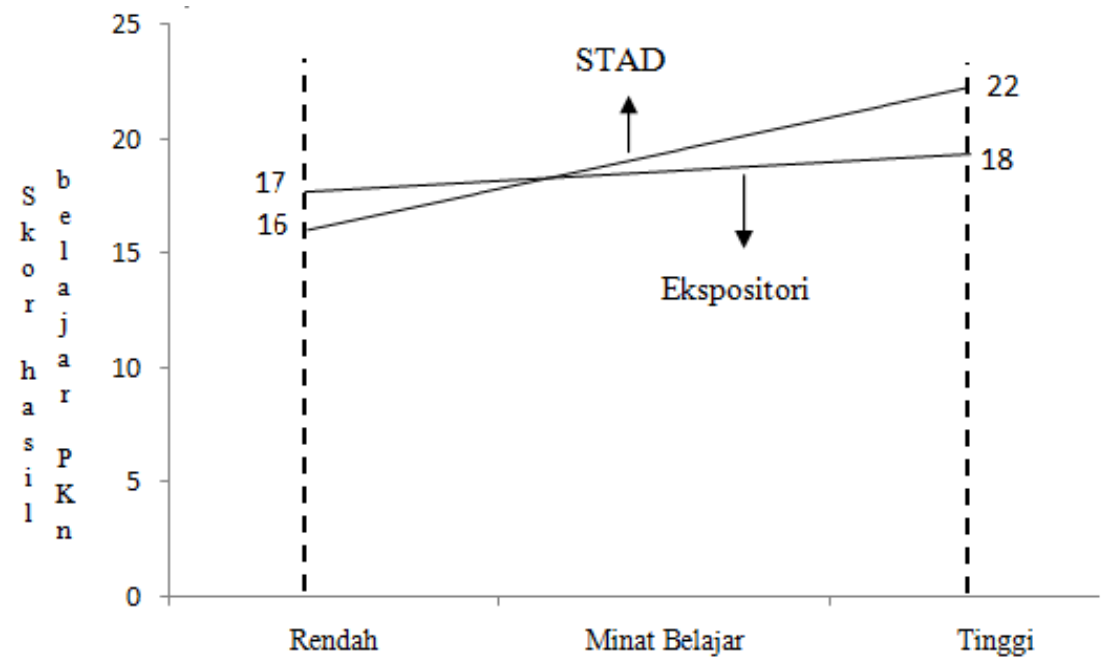

Gambar 1. Interaksi Model Pembelajaran dan Minat Belajar Terhadap Hasil Belajar PKn

Dengan terujinya secara signifikan interaksi antara model pembelajaran dan minat belajar siswa terhadap hasil belajar PKn, maka dilakukan uji lanjut. Sehubungan dengan jumlah sampel (n) pada setiap kelompok tidak sama maka dilakukan uji lanjut dengan menggunakan uji Scheffe. Rangkuman hasil uji Scheffe dapat dilihat pada Tabel 3. 
Tabel 3. Rangkuman Hasil Perhitungan Uji Scheffe

\begin{tabular}{cccc}
\hline $\begin{array}{c}\text { Nilai kelompok yang } \\
\text { dibandingkan }\end{array}$ & $\mathbf{F}_{\text {hitung }}$ & $\begin{array}{c}\mathbf{F} \text { tabel (3.58) } \\
\boldsymbol{\alpha}=\mathbf{0 . 0 5}\end{array}$ & Keterangan \\
\hline$\mu \mathrm{A} 1 \mathrm{~B} 1$ dengan $\mu \mathrm{A} 2 \mathrm{~B} 1$ & 13,93 & 2,76 & Signifikan \\
\hline$\mu \mathrm{A} 1 \mathrm{~B} 1$ dengan $\mu \mathrm{A} 2 \mathrm{~B} 2$ & 29,33 & 2,76 & Signifikan \\
\hline$\mu \mathrm{A} 1 \mathrm{~B} 1$ dengan $\mu \mathrm{A} 1 \mathrm{~B} 2$ & 21,08 & 2,76 & Signifikan \\
\hline$\mu \mathrm{A} 2 \mathrm{~B} 1$ dengan $\mu \mathrm{A} 1 \mathrm{~B} 2$ & 2,97 & 2,76 & Signifikan \\
\hline$\mu \mathrm{A} 2 \mathrm{~B} 1$ dengan $\mu \mathrm{A} 2 \mathrm{~B} 2$ & 0,77 & 2,76 & Tidak Signifikan \\
\hline$\mu \mathrm{A} 1 \mathrm{~B} 2$ dengan $\mu \mathrm{A} 2 \mathrm{~B} 2$ & 0,72 & 2,76 & Tidak Signifikan \\
\hline
\end{tabular}

Berdasarkan hasil uji lanjut dengan uji Scheffe di atas, maka dapat disimpulkan bahwa dari enam kombinasi pengujian terdapat emapt pengujian uji lanjut menunjukkan hasil yang signifikan dan dua pengujian uji lanjut menunjukkan hasil yang tidak signifikan.

\section{Pembahasan}

Hasil pengujian hipotesis pertama menunjukkan bahwa rata-rata hasil belajar PKn secara keseluruhan kelompok siswa yang mendapat perlakuan model pembelajaran kooperatif tipe STAD lebih tinggi daripada dengan kelompok siswa yang mendapat perlakuan model pembelajaran ekspositori.

Hal ini disebabkan karena penerapan model pembelajaran kooperatif tipe STAD dipandang sebagai proses pembelajaran yang aktif, sebab peserta didik akan lebih banyak belajar melalui proses pembentukan dan penciptaan, kerja dalam kelompok dan berbagi pengetahuan. Kegiatan belajar peserta didik secara berkelompok akan sukses secara akademis dibandingkan bekerja sendiri karena kerja kelompok mendorong peserta didik untuk saling membantu satu sama lain untuk mencapai hasil yang diharapkan. Model pembelajaran kooperatif tipe STAD unggul dalam membantu siswa memahami konsepkonsep sulit. Para pengembang model ini telah menunjukkan bahwa model struktur penghargaan kooperatif telah dapat meningkatkan nilai siswa pada belajar akademik dan perubahan norma yang berhubungan dengan hasil belajar.

Hal ini sejalan dengan pendapat Prawiradilaga (2012) bahwa belajar kooperatif merupakan model pembelajaran yang sudah diteliti dengan baik dan menunjukkan hasil yang memuaskan. Prinsip dasar dalam model pembelajaran kooperatif tipe STAD sebagai berikut, setiap anggota kelompok (siswa) bertanggung jawab atas segala sesuatu yang dikerjakan dalam kelompoknya, mempunyai tujuan yang sama, membagi tugas dan tanggung jawab yang sama diantara anggota kelompoknya, berbagi kepemimpinan dan membutuhkan keterampilan untuk belajar bersama selama proses belajarnya, dan akan diminta mempertanggungjawabkan secara individual materi yang ditangani dalam kelompok kooperatif. Dalam model pembelajaran kooperatif tipe STAD dikembangkan diskusi dan komunikasi dengan tujuan agar siswa saling berbagi kemampuan, saling belajar berpikir kritis, saling menyampaikan pendapat, saling memberi kesempatan menyalurkan kemampuan, saling membantu belajar, saling menilai kemampuan dan peranan diri sendiri maupun teman lain.

Pendapat di atas diperkuat oleh temuan hasil penelitian yang dilakukan oleh Esminarto, dkk (2016) menunjukkan bahwa, peningkatan hasil belajar siswa dapat terjadi karena model pembelajaran kooperatif tipe STAD adalah salah satu upaya guru untuk mencapai aspekaspek pemahaman konsep, dan lainnya yang mendorong siswa untuk aktif bertukar pikiran dengan sesamanya dan memahami suatu materi pelajaran sehingga hasil belajar siswa dapat meningkat. Selain itu model pembelajaran kooperatif tipe STAD jika diterapkan dengan baik dan benar sesuai dengan prinsip dan langkah-langkah yang telah disebutkan, dapat meningkatkan kualitas pembelajaran siswa dan juga meningkatkan hasil belajar siswa. Oleh karena itu guru harus memahami esensi pembelajaran dengan menggunakan STAD agar pembelajaran dapat terlaksana secara efektif. Dengan harapan, kualitas pembelajaran dan 
hasil belajar siswa akan meningkat.

Selain itu, temuan Zakira, dkk (2014) juga menyebutkan bahwa pembelajaran menggunakan metode kooperatif tipe STAD dianggap representatif dalam memecahkan masalah yang terjadi dalam pembelajaran, sehingga dalam setiap pembelajaran menyenangkan bagi setiap peserta didik, berpikir logis dan kritis, berkomunikasi, bekerjasama dalam memecahkan sebuah masalah dan memiliki keterampilan dalam kehidupan sosial dan kesadaran terhadap nilainilai sosial untuk meningkatkan hasil belajar siswa sekaligus meningkatkan hasil pembelajaran PKn sehingga dapat diterapkan dalam kehidupan sehari-hari di lingkungan sekitar baik secara individu, maupun kelompok.

Peranan guru dalam model pembelajaran ekspositori adalah sebagai pembimbing, memberikan penjelasan kepada siswa dan diiringi dengan memberi tugas maupun latihan. Para siswa memperoleh sejumlah pengetahuan yang diterima dari guru, namun mereka sendiri tidak dibiasakan untuk mencoba menemukan pengetahuan informasi, siswa menerima pembelajaran secara pasif. Bentuk kegiatan pembelajaran ini berlangsung dengan menggunakan guru sebagai satu-satunya sumber belajar sekaligus bertindak sebagai penyaji isi pelajaran. Siswa mengikuti kegiatan pembelajaran tersebut dengan cara mendengarkan ceramah dari guru, mencatat dan mengerjakan tugas-tugas yang diberikan oleh guru. Hal inilah kemungkinan penyebab hasil belajar PKn siswa yang mendapat perlakuan model pembelajaran ekspositori lebih rendah dibandingkan kelompok siswa yang mendapat perlakuan model pembelajaran kooperatif tipe STAD.

Senada dengan hal di atas, Dick dan Carey (1996) mengemukakan bahwa pembelajaran ekspositori cenderung menggunakan hapalan-hapalan dan lebih mengarah ke aspek memorization, yang menitikberatkan unsur ingatan, sehingga siswa memperoleh pengetahuan dan keterampilan dengan cara menghubungkan kata-kata dengan subjek secara berulang-ulang, yang pada akhirnya bila siswa belum hapal dengan sempurna, maka materi tersebut tidak dapat diteruskan atau ditambah. Dalam pembelajaran ini guru lebih banyak berperan artinya siswa tidak terlibat secara langsung dalam mencari dan menemukan materi-materi penting pembelajaran, sehingga pengetahuan dan keterampilan yang diperoleh tidak mampu meningkatkan retensi dan daya ingat siswa atau hanya berada dalam memori ingatan jangka pendek saja. Akhirnya, keberhasilan siswa dalam belajar sangat tergantung pada penyampaian guru, kemampuan, dan pengalaman guru saja. Pembelajaran seperti ini akan berpotensi untuk memberikan perolehan hasil belajar yang kurang maksimal. Jadi jelaslah model pembelajaran ekspositori merupakan model yang digunakan guru untuk menyampaikan materi pelajaran secara lisan tentang fakta-fakta, teori atau prinsip pada siswa, tanpa ikut melibatkan siswa dalam kegiatan aktif. Siswa bertindak sebagai pihak yang pasif, hanya mendengarkan ceramah guru, sehingga komunikasi hanya merupakan komunikasi satu arah.

Temuan penelitian ini juga sesuai dengan hasil penelitian yang dilakukan oleh Tumiyatun (2013) bahwa model pembelajaran kooperatif tipe STAD dapat meningkatkan partisipasi dan keaktifan siswa dalam pembelajaran PKn materi kebebasan berorganisasi. Hasil penelitian Maharini dan Lasmawan (2013) juga menyimpulkan bahwa terdapat perbedaan hasil belajar PKn yang signifikan antara kelompok siswa yang mengikuti pembelajaran dengan Kooperatif Tipe STAD dan kelompok siswa yang mengikuti pembelajaran konvensional.

Dari uraian tersebut di atas jelas terlihat bahwa hasil belajar siswa yang menyangkut aspek kognitif, khususnya kemampuan mengingat, memahami, merapkan dan menganalisis akan sangat berkembang dalam model pembelajaran kooperatif tipe STAD. Dengan demikian, jelas bahwa dengan menggunakan model pembelajaran kooperatif tipe STAD akan memberi pengaruh yang lebih baik terhadap hasi belajar PKn dibandingkan dengan pembelajaran menggunakan model pembelajaran ekspositori.

Hasil pengujian hipotesis kedua menunjukkan bahwa nilai rata-rata hasil belajar PKn siswa yang memiliki minat belajar tinggi lebih tinggi dibandingkan dengan siswa yang memiliki minat belajar rendah. Hal ini mengindikasikan bahwa siswa yang memiliki minat belajar tinggi lebih mampu memahami pelajaran PKn dibandingkan dengan siswa yang memiliki minat belajar rendah. 
Minat dapat timbul karena daya tarik dari luar dan juga datang dari hati sanubari. Minat yang besar terhadap sesuatu merupakan modal yang besar artinya untuk mencapai atau memperoleh benda atau tujuan yang diminati itu. Minat belajar yang besar cenderung menghasilkan prestasi yang tinggi, sebaliknya minat belajar yang kurang akan menghasilkan prestasi yang rendah

Hasil penelitian ini sejalan dengan pendapat yang dikemukakan oleh Djamarah (2009) bahwa minat belajar cenderung menghasilkan prestasi yang tinggi, sebaliknya minat belajar yang kurang akan menghasilkan prestasi belajar yang rendah. Senada dengan pendapat di atas temuan penelitian Muldayanti (2013) juga mengemukakan bahwa minat seseorang akan timbul bila ada kegiatan yang sekiranya disenangi. Seseorang yang memiliki minat terhadap sesuatu hal, akan merasa tertarik dan terdorong untuk melakukan kegiatan yang berkaitan dengan hal tersebut. Dengan adanya rasa senang dan tertarik akan menggunakan apa saja yang dimilikinya untuk melibatkan diri dalam kegiatan tersebut agar mendapat hasil sesuai yang diharapkan. Ketika siswa memiliki minat belajar tinggi, maka siswa tersebut akan mendapat prestasi belajar tinggi, begitu juga sebaliknya.

Kemudian hasil penelitian ini juga sesuai dengan penelitian yang dilakukan oleh Pambudi, dkk (2014) bahwa minat belajar tinggi lebih baik dalam meningkatkan hasil belajar Akuntansi daripada siswa yang memiliki minat belajar rendah.

Berdasarkan uraian di atas, jelas bahwa siswa yang mempunyai minat belajar tinggi memperoleh hasil belajar PKn yang lebih tinggi dibandingkan dengan siswa yang mempunyai minat belajar rendah.

Hasil pengujian hipotesis ketiga menunjukkan bahwa terdapat interaksi antara model pembelajaran kooperatif dan minat belajar terhadap hasil belajar PKn. Apabila dilihat dari minat belajar, rata-rata hasil belajar PKn pada kelompok siswa yang memiliki minat belajar tinggi yang diajar dengan model pembelajaran kooperatif tipe STAD lebih tinggi dibandingkan dengan rata-rata hasil belajar PKn yang diajar dengan model pembelajaran ekspositori. Selanjutnya rata-rata hasil belajar PKn siswa yang memiliki minat belajar rendah yang diajar dengan model pembelajaran kooperatif tipe STAD lebih rendah dibandingkan dengan rata-rata hasil belajar PKn yang diajar dengan model pembelajaran ekspositori. Hal ini bermakna bahwa bagi kelompok siswa yang memiliki minat belajar tinggi lebih baik diajar dengan model pembelajaran kooperatif tipe STAD dibandingkan dengan model pembelajaran ekspositori. Sedangkan kelompok siswa yang memiliki minat belajar rendah lebih baik diajar dengan model pembelajaran ekspositori dibandingkan dengan model pembelajaran kooperatif tipe STAD. Dengan demikian dapat ditarik kesimpulan bahwa model pembelajaran kooperatif dan minat belajar signifikan mempengaruhi hasil belajar PKn.

\section{PENUTUP \\ Simpulan}

Berdasarkan hasil penelitian dan pembahasan yang telah dikemukakan sebelumnya, maka dalam penelitian ini dapat disimpulkan bahwa:

1. Hasil belajar PKn siswa yang diajar dengan model pembelajaran kooperatif tipe STAD lebih tinggi daripada siswa yang diajar dengan model pembelajaran ekspositori.

2. Hasil belajar PKn siswa yang memiliki minat belajar tinggi lebih tinggi daripada siswa yang memiliki minat rendah.

3. Terdapat interaksi antara model pembelajaran kooperatif dan minat belajar dalam mempengaruhi hasil belajar PKn. Siswa yang memiliki minat belajar tinggi memperoleh hasil belajar PKn yang lebih tinggi jika dibelajarkan dengan menggunakan model pembelajaran kooperatif tipe STAD daripada model pembelajaran ekspositori, sedangkan siswa yang memiliki minat belajar rendah lebih tinggi hasil belajarnya jika dibelajarkan dengan model pembelajaran ekspositori daripada model pembelajaran kooperatif tipe STAD.

\section{DAFTAR PUSTAKA}

Dick, W \& Carey, L. (1996). The Systematic Design of Instruction. Fouth Edition. New York: Herper Collin Collage Publisher

Dimyati \& Mudjiono. (2009). Belajar dan Pembelajaran. Jakarta: Rineka Cipta

Djamarah, B.S. (2009). Strategi Belajar 
Mengajar. Jakarta: Rineka Cipta

Esminarto, dkk. (2016). Implementasi Model STAD dalam Meningkatkan Hasil Belajar Siswa. Briliant Jurnal Riset dan Konseptual. 1(1)

Ibrahim, dkk. (2010). Pembelajaran Kooperatif. Surabaya: UNESA Press

Isjoni. (2011). Cooperative Learning. Bandung: Alfabeta

Lie, A. (2007). Cooperative Learning. Jakarta: Grasindo

Maharini, I.G.AD. \& Lasmawan, W. (2013) Pengaruh Model Pembelajaran Kooperatif Tipe STAD Terhadap Hasil Belajar Ditinjau dari Motivasi Berprestasi Siswa Kelas 4 SD di Gugus I Kuta Kabupaten Bandung. e-Journal Program Pascasarjana Universitas Pendidikan Ganesha Jurusan Pendidikan Dasar. 3(1)

Muldayanti, N.D. (2013). Pembelajaran Biologi Model STAD dan TGT Ditinjau dari Keingintahuan dan Minat Belajar Siswa. Jurnal Pendidikan IPA Indonesia. 2(1) $12-17$

Pambudi, A.P., Siswandari \& Hamidi., N. (2014). Pengaruh Penerapan Model Pembelajaran Kooperatif Tipe STAD (student teams achievement division) dan TGT (Team Games Tournament) Terhadap Hasil Belajar Akuntansi Ditinjau Dari Minat Belajar Siswa (Studi Eksperimen pada Siswa Kelas XI IPS SMA Negeri XXX). Jupe UNS. 2(3)354364.

Pidarta, M. (2007). Wawasan Pendidikan. Surabaya: Unesa University Press.

Prawiradilaga, D.S. (2012). Wawasan Teknologi Pendidikan. Jakarta: Kencana

Rusman. (2011). Model-Model Pembelajaran: Mengembangkan Profesionalisme Guru Jakarta: Rajawali Pers
Sardiman. (2009). Interaksi dan Motivasi Belajar Mengajar. Jakarta: Raja Grafindo Persada.

Sanjaya, W. (2011). Model Pembelajaran Berorientasi Standar Proses Pendidikan. Jakarta: Kencana.

Slameto. (2010). Belajar dan Faktor-Faktor Yang Mempengaruhi. Jakarta:Rineka Cipta.

Slavin, R.E. (2005). Cooperative Learning Teori, Riset dan Praktik. Bandung: Nusa Media

Sudjana, N. (2009). Penilaian Hasil Proses Belajar Mengajar. Bandung: Remaja Rosdakarya.

Suprijono, A. (2010). Coperative Learning. Yogyakarta: Pustaka Belajar.

Suryabrata, S. (2008). Psikologi Pendidikan. Jakarta: Raja Grafindo Persada

Syah, M. (2010). Psikologi Pendidikan dengan Pendekatan Baru. Bandung: Remaja Rosdakarya.

Trianto. (2010). Pembelajaran Terpadu. Jakarta: Bumi Aksara.

Tumiyatun. (2013). Peningkatan Keaktifan Siswa Melalui Model Pembelajaran Kooperatif Tipe STAD pada Pembelajaran PKn Siswa Kelas V SD Negeri 03 Wonorejo, Gondangrejo Karanganyar Tahun Pelajaran 2012/2013. Jurnal Fakultas Keguruan dan Ilmu Pendidikan Universitas Muhammadiyah Surakarta Tahun 2013

Undang-Undang Nomor 20 Tahun 2003 tentang Sistem Pendidikan Nasional

Zakira, J. \& Hasdin. (2014). Meningkatkan Hasil Belajar Siswa pada Pembelajaran PKn Melalui Metode Kooperatif Tipe STAD pada Kelas V SDN Inpres Torotop. Jurnal Kreatif Tadulako Online. 5(9)9.ISSN 2354-614X 